\title{
Matices estéticos y comunicativos de la gráfica en la dictadura militar de Gustavo Rojas Pinilla*
}

\author{
Augusto Solórzano** \\ Recibido: 2016-05-12. Enviado a pares: 2016-05-18 \\ Aprobado por pares: 2016-06-01. Aceptado: 2016-06-09 \\ DOI: 10.22395/angr.v15n29a9
}

\begin{abstract}
Resumen
La presente investigación enfatiza en los matices ideológicos de imágenes realizadas durante el período de la dictadura militar en Colombia del General Gustavo Rojas Pinilla (1953-1957). La hipótesis de partida de la investigación es que la censura a la prensa, la instauración del totalitarismo y las restricciones a la libre opinión demarcan un conjunto de imaginarios culturales que anclan una modernización conservadora. Un análisis crítico y un enfoque cualitativo permiten concluir que la comunicación de la época difunde un proyecto moderno, cuya carga simbólica, estética e ideológica refleja la conciencia histórica del orden y el progreso.
\end{abstract}

Palabras clave: sistemas de representación, comunicación, estética, ideología, dictadura militar

Este texto hace parte del proyecto Historia social de la gráfica en la dictadura militar en Colombia 19531957, inscrito en el Sistema de la Investigación de la Información HERMES de la Universidad Nacional de Colombia. (COLOMBIA)

*. Doctor en Filosofía. Profesor asistente en la Universidad Nacional de Colombia, Facultad de Arquitectura, Escuela de Artes. Sede Medellín. portalsolorzano@gmail.com 


\title{
Communicative and Aesthetic Shades of a Graph during Gustavo Rojas Pinilla's military dictatorship
}

\begin{abstract}
This research emphasizes on ideological shades of images carried out during General Gustavo Rojas Pinilla's military dictatorship (1953-1957)

in Colombia

The research hypothesis is that press censorship, the establishment of totalities and restrictions to free opinion frame a set of cultural imaginaries, which secure a conservative modernization. A critical analysis and a qualitative approach allow concluding that communication of the epoch spread a modern project, which symbolic, aesthetic, and ideological load reflects the historical consciousness of order and progress.
\end{abstract}

Key words: Representation systems, aesthetic, ideological communication, Military dictatorship. 
Matices estéticos y comunicativos de la gráfica en la dictadura militar de Gustavo Rojas Pinilla

\section{Contexto que enmarca la producción de las imágenes de la Dictadura Militar (1953-1957)}

Entre los años 1953 y 1957, Colombia enfrentaba la instauración del régimen totalitario liderado por el Teniente General Gustavo Rojas Pinilla. También en Latinoamérica, países como Paraguay, Bolivia, Cuba, Haití y República Dominicana estaban sometidos a esquemas políticos dictatoriales. La industria nacional crecía a la par de la ultra-disciplina institucional y, en el ámbito sociológico, se superponía la obediencia a la legitimación democrática. En medio de este marco, los distintos medios de comunicación implementaban estrategias discursivas que reivindicaban el mantenimiento del poder como una cuestión necesaria para preservar el orden institucional. De igual modo, la imagen propagandística del Gobierno buscaba enaltecer las virtudes del modelo económico y sedimentar las bases ideológicas de la modernización en un país que durante décadas había sufrido a causa de la violencia entre liberales y conservadores.

En este punto cabe preguntarse: ¿Qué papel juegan los sistemas gráficos en la dictadura a la hora de mitificar la Modernidad? Este planteamiento inicial permite aproximarnos y entender cómo a través de la imagen, el Gobierno colombiano logra movilizar social y emocionalmente a todo un pueblo a través de valores dominantes. La mitificación de lo cotidiano, que implica un nuevo modo de ver y de sentir, está reflejada en las imágenes que circulaban diariamente.

Publicidad y propaganda del Gobierno sedimentan los requerimientos ideológicos, identitarios y comunicacionales a través de una estética difundida en los medios masivos que afianza la política estatista e impulsa la industrialización como eje del desarrollo económico nacional. Detrás de la potencialidad comunicativa de estas imágenes, operan "los mitos que juegan un papel insustituible, ya que al condensar y dar concreción a los componentes más elementales de las ideologías, facilitan su penetración en la conciencia colectiva a través del inconsciente social" (Pérez, 1988). En esta dirección, la metáfora del espejo de Atenea, de la que se vale Kracauer para asegurar que "la imagen es el reflejo que permite afrontar la realidad" (Kracauer, 1996, p. 373), elucida la manera en que el discurso gráfico se deforma en favor de las estructuras del poder hasta el punto de convertirse en el único vehículo legítimo de opinión.

Dentro de este marco, ha de considerarse que no existe ideología sin mitificaciones. La difusión de una realidad prendada por los imaginarios de progreso, confort y familia, orden, salubridad y obediencia aprovecha el inconsciente social y convierte los mitos en vehículos ideológicos para facilitar su anclaje en la conciencia colectiva (Fromm, 1979). Gracias a que el nódulo ideológico es cargado de emocionalidad, se facilita articular las necesidades objetivas del Estado con las necesidades subjetivas del individuo. Se explica así, el porqué durante la dictadura, la producción gráfica está focalizada principalmente en mitificar aspectos de la vida cotidiana y promover al Estado como institución omnipotente.

En medio de la censura a la prensa, la represión a los movimientos estudiantiles, el señalamiento a los sindicatos obreros y la intolerancia de las formas alternativas de opinión (Galvis y Donadío, 1988), los sistemas de comunicación toman un cariz particular

Anagramas Volumen 15, № 29 pp. 191-214 ISSN 1692-2522 Julio-Diciembre de 2016. 244 p. Medellín, Colombia 193 
al estar sujetos al Decreto 2535 de septiembre de 1955 titulado "Disposiciones sobre la Prensa". En él:

Se prohibía la publicación de información, noticias, comentarios, caricaturas, dibujos o fotografías, que implicaran una falta de respeto al Presidente de la República o a los Jefes de Estado de naciones amigas. Toda información que pudiera afectar al orden público estaba también prohibida. Estas disposiciones establecieron que la Oficina de Información y Prensa se hiciera cargo de aplicar las correspondientes sanciones (Cardona, 1982, p.176).

Al dar la vuelta a la página de la historia, las imágenes oficiales testimonian un episodio histórico del que surgen detalles inusitados que dan cuenta de cómo fueron representados los mitos culturales de la institucionalidad, pero también de la forma en que la imagen difundida en revistas y periódicos se convierte en ese "producto significante" que piensa Schütz (1977), que articula efectos de sentido, que construye el mundo intersubjetivo del sentido común y que origina pensamientos, conocimientos y acciones que transforman la vida cotidiana.

\section{La dictadura y los sistemas de representación}

En lo que se refiere al concepto de "sistemas de representación" hay que recordar su protagonismo a la hora de establecer los procesos de clasificación, interpretación, apropiación y circulación de la imagen. De igual modo, no puede pasarse de largo que al cambiar los sistemas de representación cambia también la historia de las representaciones (Danto, 2003), lo cual explica su importancia para la hermenéutica de lo visual, la semiótica de la imagen, la teoría crítica y los estudios culturales y visuales. Al hacer las veces de común denominador entre el sentido, el lenguaje y la cultura, los sistemas de representación modelan estética e ideológicamente lo que es legítimo, aceptable y normal. De ahí, que no sea fortuito el hecho de que estudiosos de la imagen como Lizarazo (2004), Barthes (1999), Baudrillard (1978) o Berger (1980) entre otros, apelen a la noción de sistema con miras a revelar cómo la sociedad ordena sus experiencias, configura la conducta de los individuos con la acción política y enmarca los significados y connotaciones ideológicas. En esta dirección, puede decirse que los sistemas gráficos tienen una doble función: por un lado, anclar, a través de la imagen, los mitos culturales. Por otro, permitir que en el tiempo, sus significados puedan ser asumidos y difundidos como sentido común. En otras palabras, construir y naturalizar las representaciones que, a manera de ideología, orientan ciertos valores y visiones del mundo, mientras ocultan, descalifican o manipulan otras. Hablar de sistema gráfico significa abordar los diferentes modos de organizar, agrupar y clasificar las imágenes, pero sobre todo, implica hacer una presentación sinóptica de los fines sociales derivados de ideologías operantes que activan en lo cotidiano un conjunto de valores y prejuicios que guían el accionar práctico y político del común de las personas.

En lo que respecta a la dictadura militar y los sistemas de representación hay que decir que uno de los derechos fundamentales de la democracia es reconocer el valor polisémico de los mensajes comunicacionales, pues se asume que los receptores orientan sus propios intereses e interpretaciones tutelados por la brújula de sus necesidades. Usar 
activamente las representaciones de los mass media es reconocer que la audiencia tiene el derecho de jugar un rol activo en la comunicación sobre la base de que en las estrategias comunicativas prevalecen las visiones de quienes las estructuran. Contrario a esto, en la dictadura, los eventos se codifican de una sola manera que difunde exclusivamente los intereses, gustos y valores de una clase hegemónica. De este modo, se limita la posibilidad de que la audiencia interprete total o parcialmente el mensaje o, por lo menos, se incide en el valor de las interpretaciones, supeditando la circulación, los efectos y las reacciones a intereses claramente políticos e ideológicos del poder. Sobre esta articulación entre discurso y poder es que Foucault (1999) reclama identificar las condiciones sociales y culturales desde la cuales se regula el discurso, pues no se trata simplemente del ejercicio del poder como el uso de la fuerza para subyugar a otro, sino de la capacidad que los discursos tienen para producir socialmente los significados.

Los ejemplos presentados aquí reflejan unos imaginarios embebidos en formas normativas que interrelacionan la realidad social conflictiva con el ejercicio castrense del poder, y más que nada, con el intento de restaurar el viejo orden católico conservador en una nación golpeada por la violencia política. El telón de fondo de este sistema gráfico hace evidente un modelo homogeneizador basado en el deber ser, núcleo que difunde la imagen de un proyecto histórico de Nación. De ahí se entiende el interés que el Estado otorga a la televisión como medio oficial y agente socializador con el que se pretende ofrecer a la audiencia una interpretación diferente y progresista de la realidad. A esto Castells (1998) se referirá como "identidad legitimadora", introducida por las instituciones dominantes de la sociedad para llevar a cabo y racionalizar su dominación frente a los actores sociales (Castells, p. 30). En el otro extremo de la balanza, se encuentra un sector de la prensa que adopta una "identidad de resistencia", mantenida por "actores que se encuentran en posiciones devaluadas o estigmatizadas por la lógica de la dominación de la sociedad" (Castells, p. 30), que sobrevive en medio de una dictadura fiscalista disfrazada de democracia lírica y jurídica con marcados intereses económicos y cristianos.

La mitificación de lo cotidiano, sinónimo de una nueva actitud perceptiva y expresiva que expande un mercado bajo la atenta mirada de la industria, logra su éxito gracias al poder difusivo que la imagen tiene en los medios de circulación. Distintos son los nombres que recibe este proceso de mitificación. Para Eco, se trata de una simbolización inconsciente, de la que dice, es "una suma de finalidades difícilmente realizables que, proyectadas en la imagen, dan cuenta de los temores y aspiraciones de un individuo o una comunidad" (1997, p. 219). Para Dorfles, es más bien un juego propulsor que "aviva la tradición, la devoción, el hábito, la superstición o, si se prefiere, las costumbres con todo lo que ello implica" (1969, p. 17). De cualquier forma, de lo que se trata es de una cooperación de fuerzas de sentido ético, estético, ideológico y político que generan los sistemas de representación y que la publicidad difunde sistemáticamente en revistas de moda, páginas de periódicos, cartillas escolares o pantallas de televisión. Aunque pertenezcan a territorios diversos, son capaces de organizar constelaciones visuales "porque nuestra mirada, que ha entrado en un régimen perceptivo peculiar, se encarga de agrupar unas imágenes con otras" (Català, 2005, p. 46).

Anagramas Volumen 15, № 29 pp. 191-214 ISSN 1692-2522 Julio-Diciembre de 2016. 244 p. Medellín, Colombia 195 
Converge aquí un claro interés por encontrar un común denominador entre una economía política de la dictadura, y lo que podría considerarse una historia social de la imagen técnica. Para esto, la razón práctica toca tangencialmente fenómenos sociales que surgen de la comunicación, entendida como práctica sociocultural sobre la que se opera intencionalmente.

Del conjunto de imágenes recolectadas, se evidencia que la idea de orden y progreso obedece a un entramado comunicativo que, bajo el manto estético, involucra, las relaciones productivas, la política, la religión y la ideología. La escogencia realza los goznes del imaginario del poder que fue producido en un tiempo y lugar específico. De ahí que en todo esto se realce el concepto de "conocimiento contextualmente situado" (Harawey, 1995) con el que se busca destacar una visión epistemológica que adquiere sentido en la medida en que la imagen se teje con su urdimbre ideológica y su trama estética. Bajo este marco, el sistema de representación que consolida la efectividad de mitos e imaginarios de la dictadura deja entrever los alcances que tuvo el discurso comunicacional a la hora de configurar saberes y prácticas que hicieron parte de una forma de vida, que corresponden a un proceso de hibridación entre agencias de naturaleza material y simbólica.

Es aquí donde entra en juego la estética como punto coyuntural entre la opinión y la emoción, entre lo cotidiano y lo ideológico o, si se prefiere, entre la retórica comunicativa y la pragmática contextual. Estas dicotomías hacen que la naturaleza y la calidad de las imágenes que circularon en la época animen a encontrar nuevos sentidos que vayan más allá de un problema estilístico, histórico o cronológico.

Pensar en cómo se produce la imagen, cómo circula y cuáles son los intercambios de significado que surgen es, por tanto, pensar en la forma en que la imagen, la ideología y la cultura están interconectadas y movilizan el sentido y el mito moderno del progreso. Adentrarse en estos sistemas presupone identificar la presencia de códigos a partir de los cuales razonamos, comprendemos y construimos modelos mentales de las circunstancias, las situaciones y los procesos. A esto se refiere Català cuando menciona la "importancia de pensar en las imágenes pero también con las imágenes para poner de manifiesto su particular fenomenología y los problemas epistemológicos, cognitivos y estéticos que la misma conlleva" (2005, p. 22).

Estas aproximaciones a la noción de "sistema" están presentes en Wittgenstein (1998), Goodman (1976) y Danto (2003), para quienes las formas de representación se convierten en modelos de la realidad. Los detalles y aportes que cada uno de estos autores hace permiten sostener la hipótesis de que la recolección y análisis de esta gráfica (1953-1957) no es tanto reconstruir o representar un pasado inexistente, sino sacar a la luz lo que permanece oculto tras las apariencias. Dicho de otro modo, volcar la mirada hacia la noción de sistema busca demostrar que la memoria no es una reconstrucción del pasado, sino una exploración de lo invisible, conforme lo diría Vernarnt (2000, p. 22).

Más que encontrar respuestas totalizantes, se abren varios interrogantes sobre la manera en que la sociedad ordena las experiencias, defiende las estructuras de creencia y valor, superpone y enfrenta las ideologías, a tal punto de debilitar unas y reforzar otras. En el epicentro de este asunto, se encuentra el poder persuasivo de la imagen, el cambio de decorado cultural que acarrea la incursión de los nuevos medios masivos de comu- 
nicación y una mitificación de lo cotidiano que les permite a las personas estructurar el mundo de manera significativa.

\subsection{Metodología y recursos interpretativos de la mitificación de lo cotidiano (1953-1957)}

Partiendo de la base de que toda imagen es un modo de ver y que el contenido de los mensajes enmarcan convicciones ideológicas y normas morales (Berger, 1980), se muestran, a continuación, 20 imágenes pertenecientes a divulgaciones periódicas de alta circulación en el país: El Tiempo, El Espectador, El Colombiano y la Revista Cromos. Estas publicaciones seriadas fueron consultadas siguiendo el criterio de búsqueda de hallar imágenes que dieran cuenta del sistema gráfico que se produjo durante la dictadura teniendo presente la máxima de Berger (1980) acerca de que las imágenes nunca se perciben aisladamente sino en constelaciones y que su unión va más allá de su mera contigüidad. Así, anuncios, publicidades, caricaturas, campañas de gobierno e ilustraciones anclan una visión de la realidad y fundamentan un nuevo tipo de miraba sobre las aspiraciones colectivas. El total de imágenes recolectadas fue de 346, clasificadas por un historiador en fichas que referencian el título del periódico, título de la publicidad o campaña, marca, producto o empresa emisora, tipo de producto y la ubicación cronológica. Las imágenes fueron distribuidas de la siguiente manera: 127 del Tiempo (años 1953 1955); 113 de El Espectador (años 1953 a 1955); 58 del Colombiano (años 1953 a 1957) y 46 de Cromos (años 1953 a 1957). Se asume que en ellas son evidentes características críticas e ideológicas, cuya representación descriptiva refleja que "la distancia epistemológica se traduce en un acercamiento hermenéutico" (Català, 2005, p. 24).

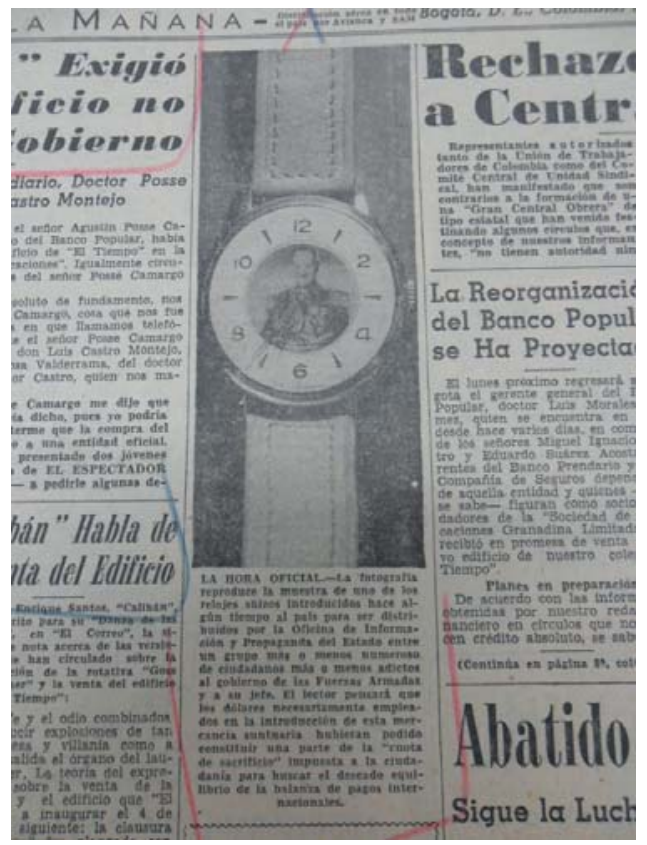

Gráfica 1. La hora oficial en Colombia.

El Espectador 6 de noviembre de 1955, p. 1 
La modernización conservadora (Moore, 1991), que defendía los intereses capitalistas y las formas de autoridad, asumió que publicaciones como El Tiempo o El Espectador amenazaban el conservadurismo oficial y oficialista. Por esta razón, planifica la censura e intervención estatal sobre la prensa en dos niveles. Por un lado, cierra tajantemente las publicaciones que no aceptaron los filtros informáticos establecidos por el Gobierno. Por otro, interviene en aquellos que mantiene abiertos promoviendo comunicaciones que afirman imaginarios sociales referidos a la estabilidad política, el orden, el progreso y la organización social y cultural del país.

Llamativo es el caso de El Tiempo, clausurado el 3 de agosto de 1955 por supuestos malos manejos en una información referida al asesinato selectivo de un periodista liberal y de su hijo en el Eje Cafetero, a manos de conservadores radicales conocidos como "Los pájaros". La negativa del director a retractarse de esta información llevó al Gobierno a expedir el Decreto 036 de 1955 en cuyos apartes se lee "A partir del 4 de agosto de 1955, el país ha quedado notificado de que el Jefe del Estado está en el palacio de los presidentes y no en la redacción de ningún diario". Esto da una idea de cómo el radicalismo contra la prensa liberal cohesiona y tranquiliza a los simpatizantes del régimen que ven en las editoriales e imágenes una propaganda adversa a los intereses dominantes. De modo similar, El Espectador se vio forzado a cerrar sus puertas el 6 de enero de 1956 a raíz de una gran multa impuesta por el Estado que no pudo ser cubierta por los editores. Aunque más sutil que la censura contra El Tiempo, esta coacción a la libertad de prensa es el indicativo de la capacidad abusiva y arbitraria del poder. Importante es mencionar que el éxito de esta estrategia no sería completo sin el apoyo de los medios y la difusión de esquemas comunicativos de inequívocos signos dictatoriales. Esto es lo que sucede justamente con el periódico El Colombiano y la Revista Cromos. Ambas publicaciones de corte conservador transmitieron y facilitaron la instauración de un discurso optimista que, a través de estereotipos, proyectaba hacia el futuro una visión progresista, romántica, bella e idealizada del país. Dado que permanecieron ininterrumpidamente activos durante los años de la dictadura, sus imágenes constituyen un valioso material que refleja la ideología de cambio traducida en mensajes de orden, deber y religión. Así, por ejemplo, "Cromos se especializó en temas femeninos tales como decoración, moda, etiqueta y demás contenidos que guiaron a las mujeres del momento sobre la forma correcta de dirigir sus hogares según los preceptos que dictaba la Modernidad" (Gómez, 2008 p. 15). En esto se evidencia el poder indisociable del binomio estética e ideología que hace que los imperativos dominantes se disuelvan en reflejos espontáneos anclados por la vía de la sensibilidad:

El poder se inscribe ahora en minucias de la experiencia subjetiva, y la fisura entre el deber Abstracto, y la inclinación placentera queda por tanto salvada. Disolver la ley en costumbre, en un hábito por completo irreflexivo, supone identificarla hasta tal punto con el propio bienestar placentero del sujeto humano que la transgresión de esa Ley significaría una profunda autoviolación. El nuevo sujeto, que se impone a sí mismo de manera autorreferencial una ley de acuerdo con su experiencia inmediata, y que encuentra su libertad en su necesidad, se modela a la luz del artefacto estético (Eaglenton, 2006, p. 74) 
Las palabras de Eaglenton Resumen la forma en que la ideología propia de una modernización conservadora instaura los modelos de buen ciudadano, buena familia y buena sociedad. Del mismo modo, dan cuenta de cómo la estética traduce las ideas dominantes en formas de la subjetividad y orienta la praxis hacia una autorrealización en la vida política. De ahí el peso que las ideas de felicidad, bienestar y progreso tienen en los mensajes oficiales, peso que aboga para que el poder absolutista sea asumido como acuerdo espontáneo, como unidad armoniosa que encarna el decoro moral.

Es importante resaltar el valor que la periodicidad de los medios tiene a la hora de establecer el ritmo sincopado que satura el ambiente con informaciones de pregnancia tal, como si se tratara de una máquina de producir presente.

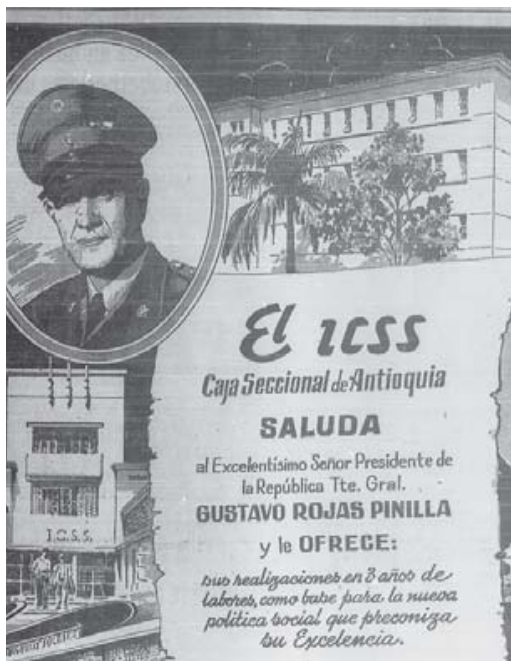

Gráfica 2. El ICSS Caja Seccional de Antioquia Saluda al Teniente General Gustavo Rojas Pinilla

El Colombiano 15 de agosto de 1953, p. 9

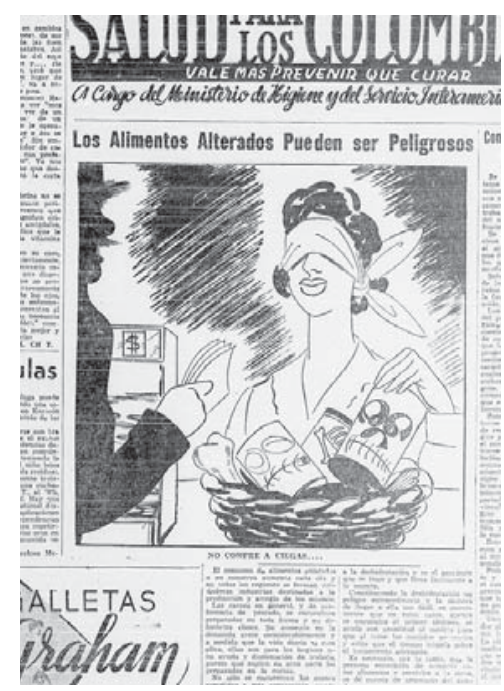

Gráfica 3. Alimentos alterados pueden ser peligrosos.

El Colombiano 25 de Enero de 1954, p. 18 
Teniendo presente el objetivo de indagar por los imaginarios sociales de la época, es posible ver cómo la modernización del país está fundamentada en el consumo y aplicación de desarrollos técnicos y tecnológicos que consecuentemente pondrían a Colombia a la par de otros países del mundo. La modernización conservadora propició el desarrollo de un discurso nacionalista que tenía como objetivo insertar al país en unas dinámicas económicas mundiales por medio de la actividad industrial. Aunque es sabido que estas iniciativas e intenciones por modernizar al país no fueron novedad del gobierno de Rojas Pinilla, sí tomaron la fuerza necesaria para instaurarse de manera profunda y permanente en el imaginario colectivo de los colombianos una vez "recupera la linealidad sintagmática y la convierte en columna de su representación" (Català, 2005, p. 46).

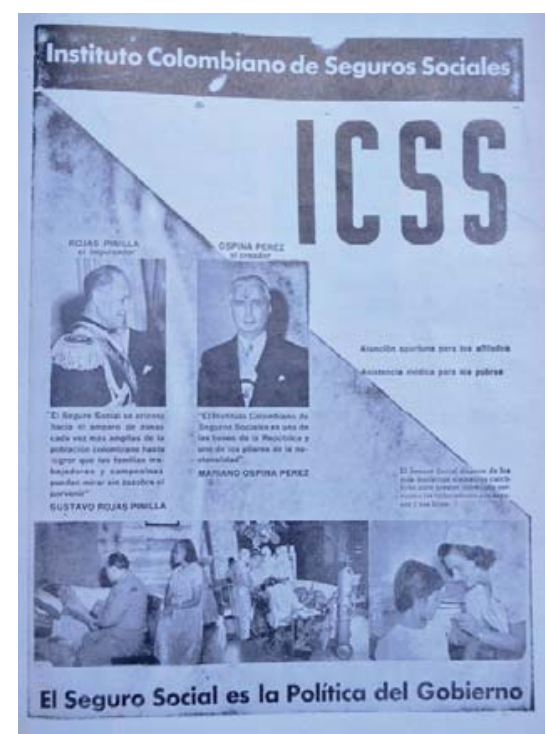

Gráfica 4. Instituto Colombiano de los Seguros Sociales.

El Colombiano, 1 de febrero de 1954, p.4

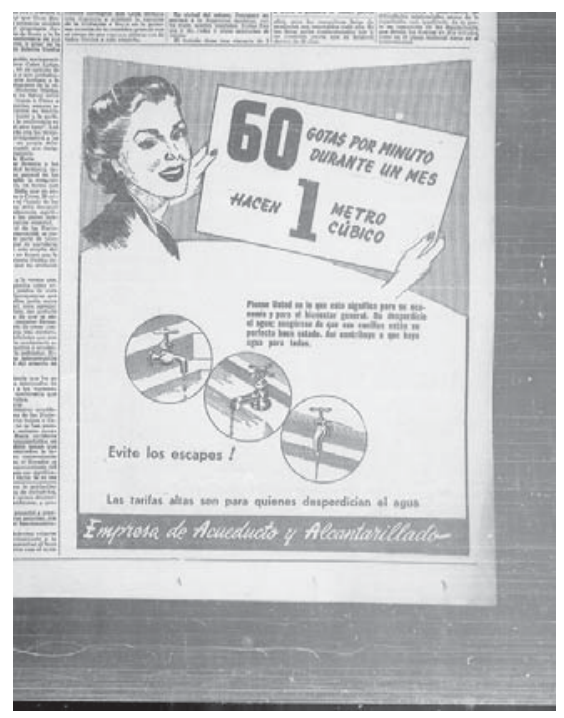

Gráfica 5. Campaña de ahorro de agua. Empresa de acueducto y alcantarillado.

El colombiano 15 de agosto de 1953. P. 11 
Los anteriores ejemplos son apenas una pequeña muestra de cómo la modernidad conservadora mitifica las experiencias de sentido en el cotidiano. Al tiempo, evidencian la forma en que la dictadura apela a la imagen para mantener la estabilidad y el control del poder, y para esto, analiza, selecciona, organiza y redistribuye los discursos producidos. Por tanto, cuando se habla de la imagen moderna en Colombia, es imposible dejar de pensar en los procedimientos de exclusión utilizados por las instituciones oficiales como mecanismos de poder contra todos aquellos discursos situados al margen de lo reglamentado, que representan peligros potenciales para la estabilidad del régimen.

La gramática de la imagen puesta a disposición del discurso del poder refleja el modo en que los medios de comunicación eran dirigidos y administrados por la dictadura. Prueba de ello son las constantes condecoraciones y homenajes que las empresas públicas y privadas le hacían al dictador como muestra de fidelidad y empatía ideológica. El ICCS de Antioquia es un ejemplo paradigmático que abre la pregunta sobre cómo los vínculos ideológicos permearon instituciones públicas y cómo desde allí se ejerció presión sobre el cuerpo social.

\subsection{Perspectivas ilustradoras de los valores ideológicos}

En lo referente al contexto publicitario se resaltan los valores modernos que promocionaron el consumo de diferentes bienes y servicios como electrodomésticos y automóviles o la aviación y televisión. Maximizando el alcance y la confiabilidad del discurso oficial, la publicidad fue determinante para ratificar la manera en que el país intentaba inscribirse en unas dinámicas industriales que requerían de la tecnificación de las comunicaciones, el transporte e incluso del hogar. Sumado a esto, es posible apreciar la forma en que la sugestión se instala por igual en el discurso político como en la publicidad. De allí se entiende la creciente y ampliamente difundida idea de aprender idiomas, oficios y profesiones aportantes para la modernización del país. Periódicos y revistas se encargan de representar una condición existencial basada en modelos extranjeros que ofertaban servicios por los que se debía pagar. Así, el mensaje de la dictadura se traduce en la conformación de una sociedad que busca en la industrialización la salida a los macro y micro problemas. No se trata solo de empleo o dinero. Es más bien de la búsqueda de un proyecto común, cuyo rasero es el catolicismo extremo, y su orientación ideológica se traduce en sustratos existenciales y patrones de consumo. Para el caso, basta volver la mirada sobre la publicidad de los buses que adquiere Bogotá. Allí se hace evidente la sustitución de un discurso marginal por uno moderno. El viejo tranvía halado por caballos es ahora cosa del pasado, una añoranza romántica que debe ser sustituida por una flota moderna de trasporte que entre a satisfacer las necesidades de ciudad moderna que crece a ritmo acelerado. 


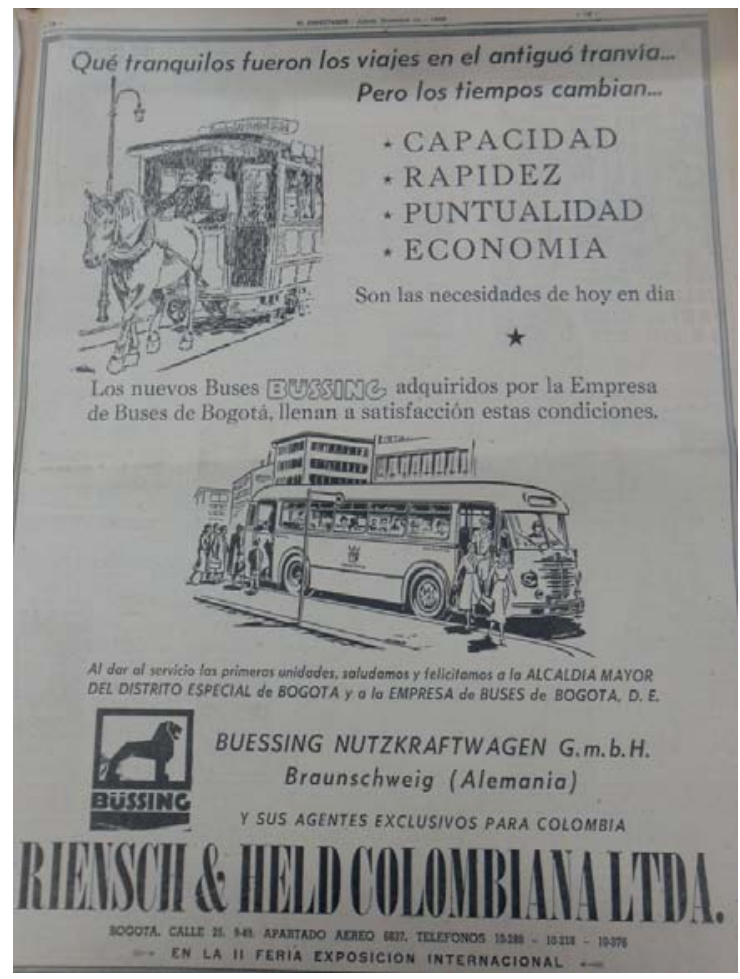

Gráfica 6. Que tranquilos fueron los viajes en el antiguo tranvía... pero los tiempos cambian.

Riensch \& Held Colombiana Ltda.

El Espectador 14 de diciembre 1955 p. 15

El concepto de justicia social fue la plataforma ideológica para lograr gran popularidad entre una amplia gama de la población, sobre todo al inicio, cuando gran parte de la sociedad tenía sobre ella una valoración positiva (Rodríguez, 2006). Conforme lo señala Bal (2009), los conceptos son teorías en miniatura que necesitan ser "explícitos claros y definidos" (p. 29). Aquí, el concepto traducido en imagen hizo las veces de puente entre las bases sociales y los ideales simbólicos e institucionales materializados en logotipos y campañas que alentaban a mantener la cohesión social.

Pero gran parte de la sociedad colombiana nadaba entre las aguas de los discursos que se proponían como soluciones a las necesidades y deseos de la realidad, y por otro lado, sentía el peso de un discurso reduccionista y antidemocrático que violaba los derechos humanos y que impedía la participación social. Una conclusión que surge al analizar la gráfica de la época, evidencia que el progreso y el desarrollo se asumieron como mera ilusión que en la superficie creaba pliegues sobre pliegues, territorializando flujos ideológicos mientras arrinconaba el derecho de expresarse libremente. 

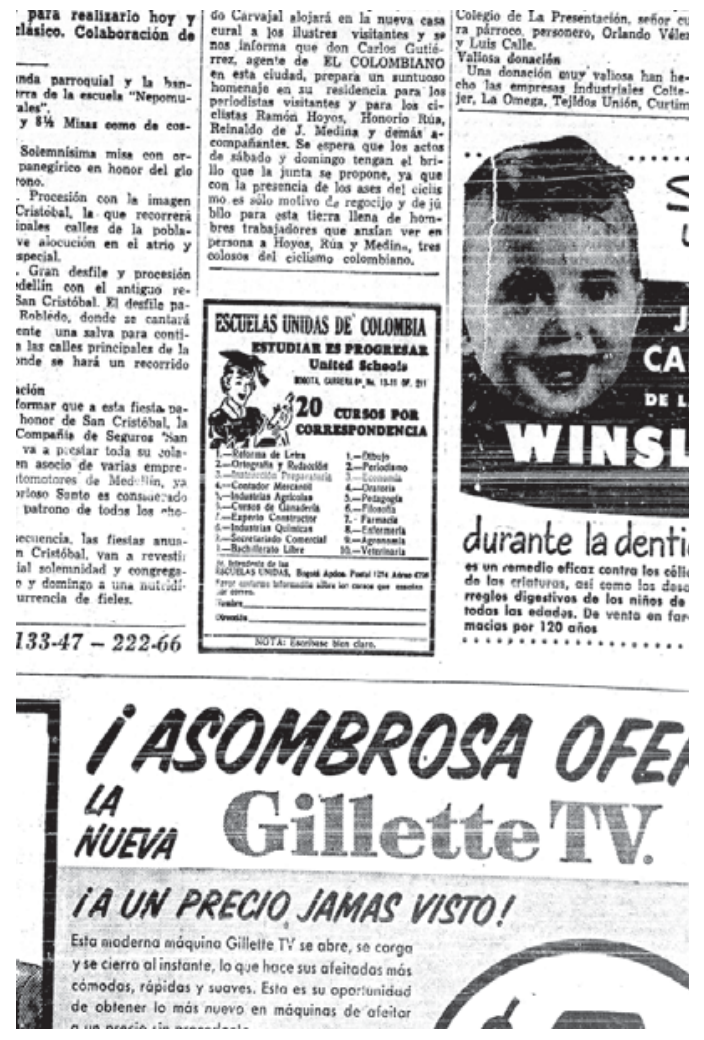

Gráfica 7. Estudiar es progresar. Escuelas Unidas de Colombia

El Colombiano 28 de julio de 1956, p. 8

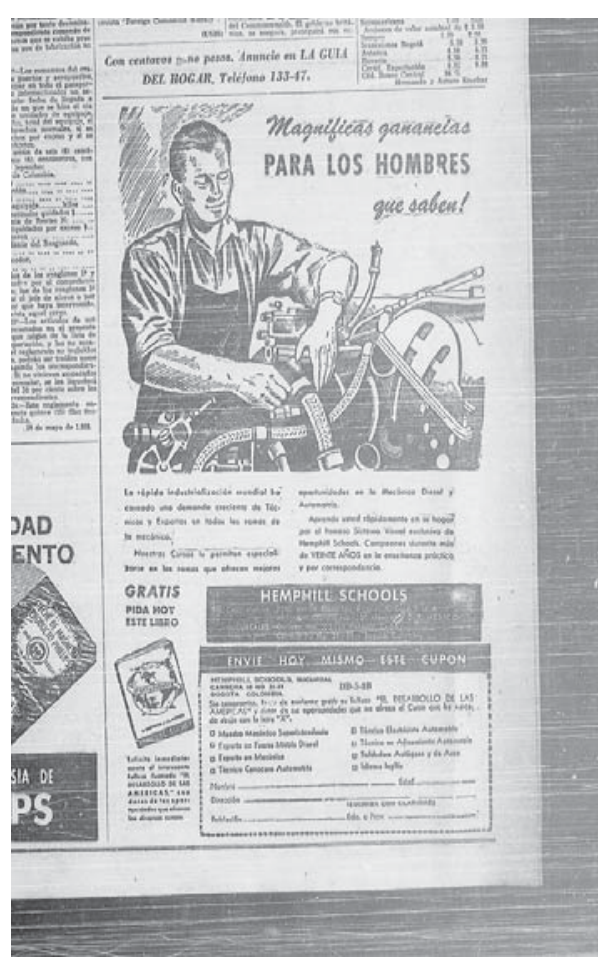

Gráfica 8. Magníficas ganancias para los hombres que saben. Hemphill Schools El Colombiano 31 de mayo de 1953. P. 7 
La idea de una modernidad que guía el progreso es reiterativa en imágenes que exaltan el trabajo y el compromiso de los ciudadanos. Hacer avanzar el país es también una apuesta por mejorar la calidad de vida, y para ello es prioritario apoyar la industria nacional y consumir lo que el país produce, bien sea una camisa o un par de zapatos, una cerveza o el cemento con el que se construye.

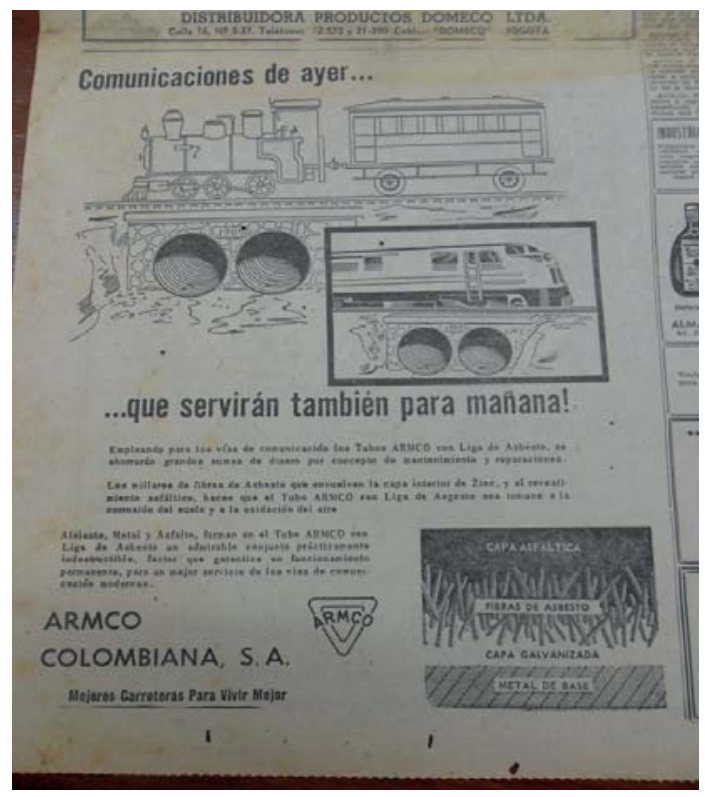

Gráfica 9. Comunicaciones de ayer que servirán también para mañana. Armco Colombiana S. A.

El Espectador, 12 de diciembre de 1955, p. 2

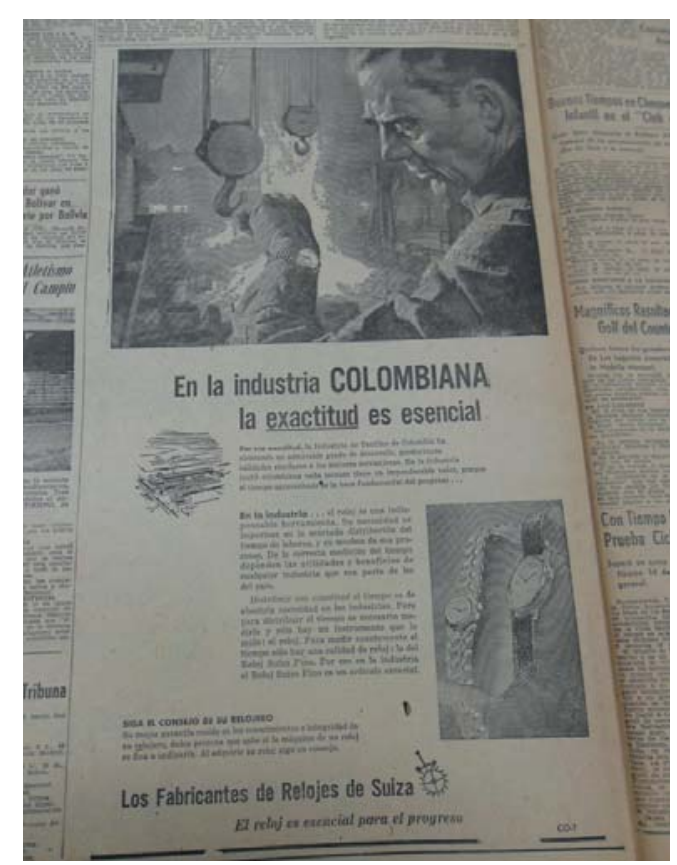

Gráfica 10. En la industria colombiana la exactitud es esencial. Fabricantes de relojes Suiza

El Tiempo, 8 de febrero de 1955, p. 16 
El desarrollo y fortalecimiento la industria colombiana se evidencia en una suerte de nacionalismo publicitario que apela a la persuasión y adopta como su discurso la industrialización moderna y la fidelidad hacia las instituciones. Bavaria, que antes de la dictadura promovía una publicidad enfocada en el individuo-consumidor (mujeres y hombres jóvenes), se vuelca hacia el ideal desarrollista y comienza a ilustrar en sus campañas la fábrica como su símbolo trascendental. De igual modo lo hacen empresas como la multinacional CocaCola y los fabricantes de relojes de Suiza que apelan a una estrategia similar, exhibiendo en sus publicidades el imaginario de ser una gran industria que propicia y abandera el progreso del país. Bajo la idea de la industrialización, subyace otro imaginario capital: el de un bienestar colectivo para el que lo individual es visto como un discurso marginal que se aparta de los ideales trazados por la dictadura. Lo colectivo exalta la idea idílica de una industria donde las personas trabajan con entusiasmo y alegría en pro del progreso del país. Haciendo uso de la motivación, la publicidad integra en la imagen un modelo de actitudes que convierten la fábrica en un lugar de encuentro para la socialización. El pseudoevento como dice Boorstin (1961), "construye la ilusión de satisfacer expectativas exageradas de grandeza humana y con ello rompe el viejo molde del "héroe" para fabricar en su lugar modelos humanos comercializables masificados para satisfacer el mercado libre de ataduras" (p. 214).

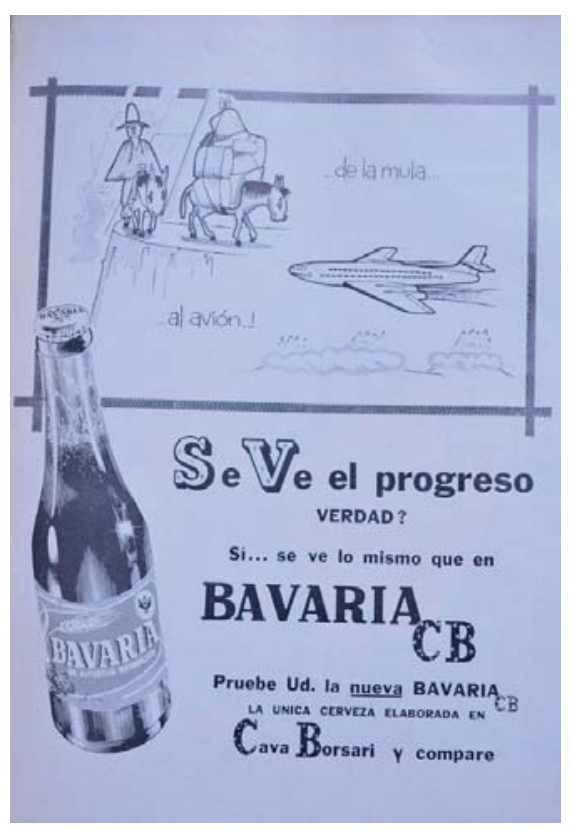

Gráfica 11. Revista Cromos. Febrero 11 de 1957, p. 8

Industrias como Coltejer, Pielroja o Croydon también incluyen en sus publicidades el valor de lo colombiano como estrategia que vehicula ideológicamente el progreso, la nación y el consumo. Con esto se intenta cerrar el círculo de producción, circulación y consumo dentro de los valores de modernidad y progreso, en procura de hacer que el consumidor promedio se sienta orgullo de su país y adopte una férrea convicción de pertenencia e identidad. Es imposible no leer en esto un claro intento por resarcir las identidades cultu- 
rales dispersas para hacerlas converger en un solo referente simbólico y hegemónico que se reconozca en el nacionalismo. La capacidad emotiva de la imagen hace las veces aquí de hilo reparador de la identidad nacional. El nivel estético que se utiliza para producir el discurso busca antes que nada determinar la opinión en el público e imponer modos de vida asociadas al consumo obligado.

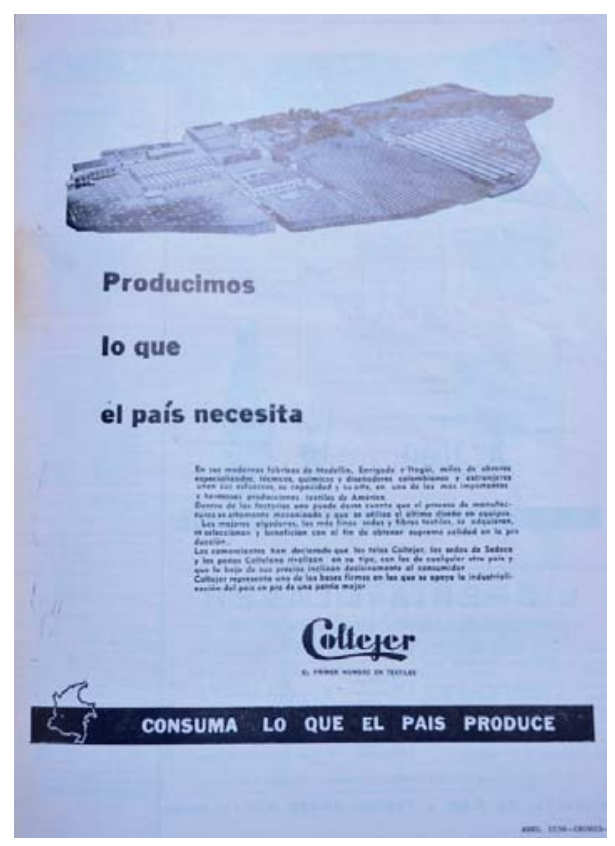

Gráfica 12. Producimos lo que el país necesita. Coltejer Revista Cromos. Abril 12 de 1954, p. 15

Ahora bien, al observar más de cerca este fenómeno, es curioso ver cómo tales valores identitarios impulsados por la publicidad se fundan sobre modelos, ideas o símbolos importados, ratificando antes que nada, que todo discurso moderno es producido en una trama semiótica transnacional. Esto, más que una crítica, es un llamado de atención a observar con detenimiento cómo se traslapan en nuestra cultura la identidad, la diversidad, la memoria y la participación social a través del consumo. La identidad es fácilmente observable en algunas de las publicidades de la época en las que el abrumador modelo consumista logra invisibilizar gran parte de la realidad social del país. Aun cuando se promulguen los valores nacionales, las imágenes de la dictadura son producciones híbridas fundamentadas en los microeventos que lo moderno establece para lo cotidiano, convertidos en producciones universales gracias a la retórica de un discurso publicitario imprescindible para formar la mentalidad del ciudadano-consumidor. 


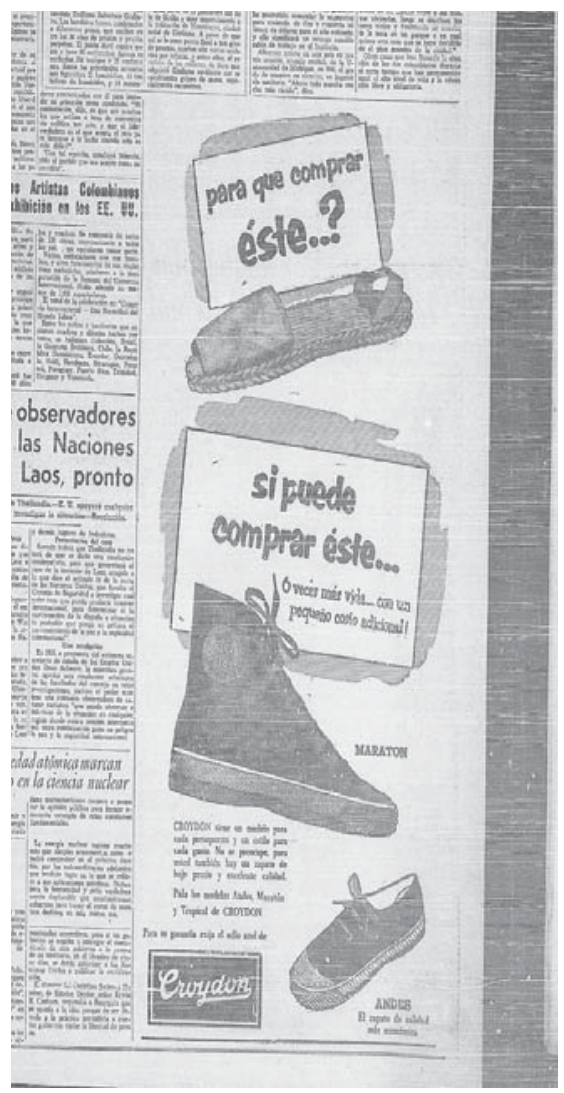

Gráfica 13. Para que comprar este?, si puede comprar este. Croydon.

El Colombiano. 22 de mayo de 1953. p, 9

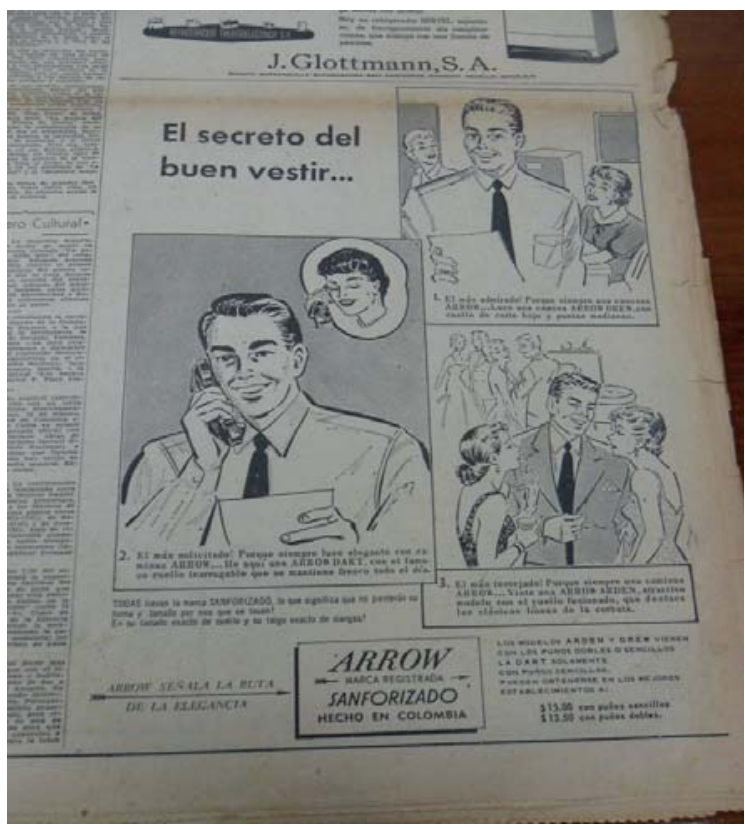

Gráfica 14. El secreto del buen vestir. Arrow.

El Tiempo. 16 de febrero de 1955, p. 5 
La hermenéutica de este mensaje ilustra claramente cómo el imaginario de modernización colombiano carga connotativamente lo autóctono de preconceptos y estereotipos importados para encajar en una sociedad de consumidores. En el fondo, la imagen trata de la oposición entre los valores nacionales y los valores regionales, entre lo civilizado y lo salvaje o, si se prefiere, entre lo formal regulado y lo informal no regulado.

Este ejemplo hace caer en la cuenta al lector de que si bien el grueso de la población adoptó la idea de progreso nacional y buscó entrar en esa lógica moderna del consumo, gran parte del país se hallaba al margen de la realidad que prometía esta ideología nacionalista y progresista, y más aún, gran parte de la población, los llamados "consumidores imperfectos" (Bauman, 2016), no disponía de los medios para entrar en esa afamada modernidad progresista.

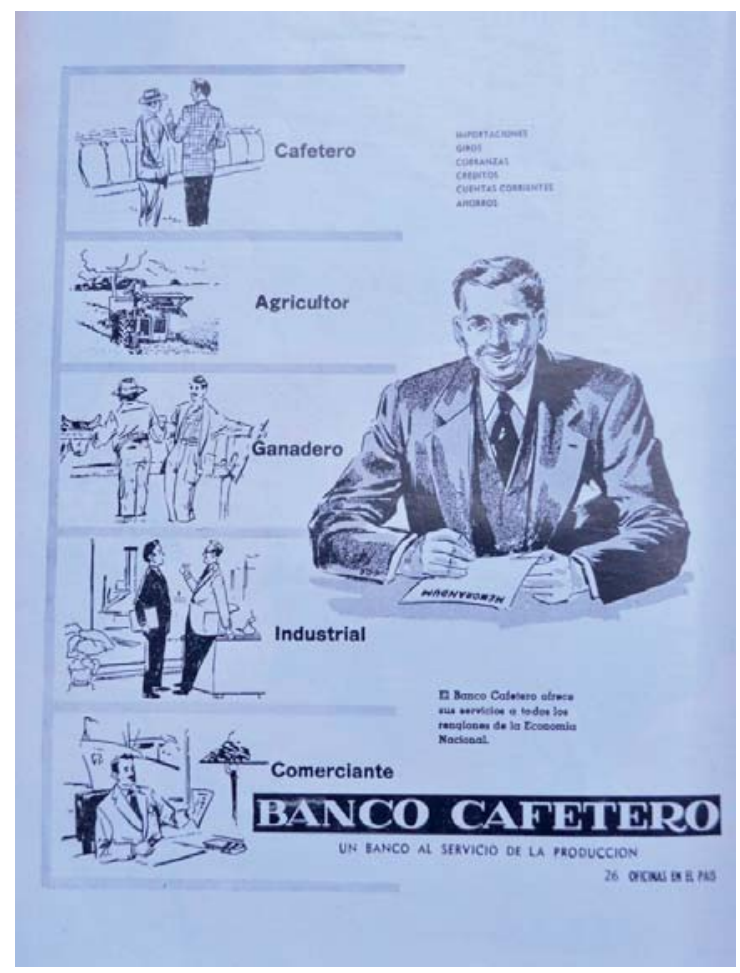

Gráfica 15. Banco Cafetero

Revista Cromos, noviembre 20 de 1957

Continuando con el discurso gráfico y publicitario, lugar donde se ejerce la separación, la delimitación y la organización de los diferentes discursos, vale traer a colación la publicidad del Banco Cafetero que circuló en periódicos y revistas del país. En ella, distintos segmentos de la sociedad son convertidos en soportes de una distribución institucional que ejerce sobre los otros un poder de coerción. El juego de valores impartido desde la institucionalidad enfatiza en modelos estereotipados del comerciante, el industrial, el cafetero, el ganadero y el agricultor. Llama la atención el del campesino que opera un tractor, imagen cuya génesis difiere de la realidad y que al adoptar como modelo de representación simbólica al trabajador tecnificado, intensifica el discurso marginal de la 
mayoría de labriegos que no disponen de maquinaria para sus tareas diarias. Se enraíza así un discurso que busca despertar el agrado intensificando el rol y que aun cuando esté desdibujado de la realidad, acentúa estímulos que reivindican la aspiración de ingresar a la fuerza a la Modernidad. Así, la imagen traduce conceptos que integran aspectos subjetivos y objetivos de la experiencia diaria.

Otro de los ámbitos en el que se registra el ideario de la dictadura fue el tema de la salud. Es ampliamente sabido que el Gobierno buscó instaurar instituciones y programas que promovieran las políticas públicas de salud. Herencia de ello son el Ministerio de Salud Pública y el Instituto de Seguros Sociales, que fueron ampliamente publicitados en los medios impresos como propaganda estatal escenificando públicamente aspectos de la vida privada.

La capacidad de traducir la política higienista en un sustrato existencial, y que de fondo esconde claras pretensiones de erradicar lo marginal, se tradujo en discursos con altos contenidos estéticos e ideológicos focalizados en la promoción de la salud y el cuidado de los niños. De ahí se entiende la importancia que se les otorga a estas entidades que, más que ser focos de bienestar social, están pensadas como entes reguladores del orden, el control y el poder, al igual que sucede con el urbanismo o la educación.

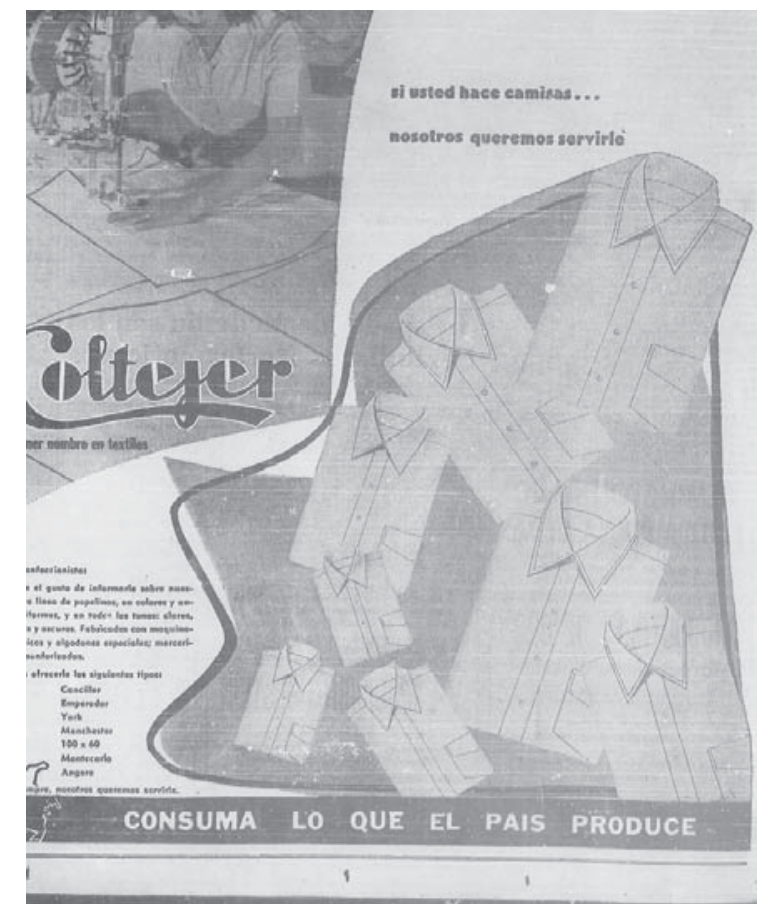

Gráfica 16. Consuma lo que el país produce. Coltejer

El Colombiano 15 de agosto de 1953. P. 26 


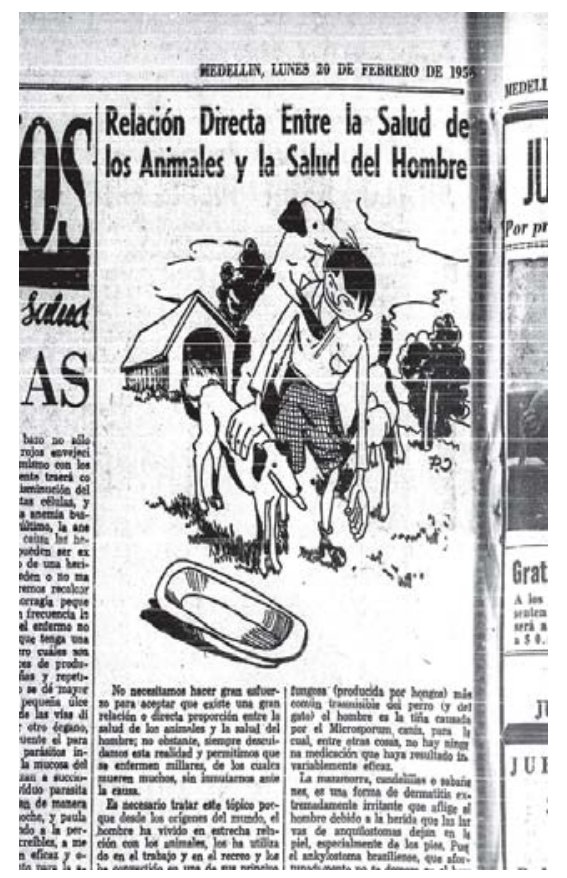

Gráfica 17. Relación directa entre la salud del hombre y los animales

El Colombiano, 20 de febrero de 1956, p. 226

Campañas estatales y notas de prensa evidencian cómo se puso a rodar un discurso con marcados tintes populistas. Merecida atención despiertan las campañas del Instituto Colombiano de Seguros Sociales que acentúan el imaginario de la salud como una forma de progreso nacional y de justicia social, pues a fin de cuentas, "las historias que más éxito tienen son las que conectan con las ansiedades, las esperanzas y las aspiraciones más generales, pero también más particulares desde el punto de vista de la experiencia" (Bauman, 2016, p. 17).

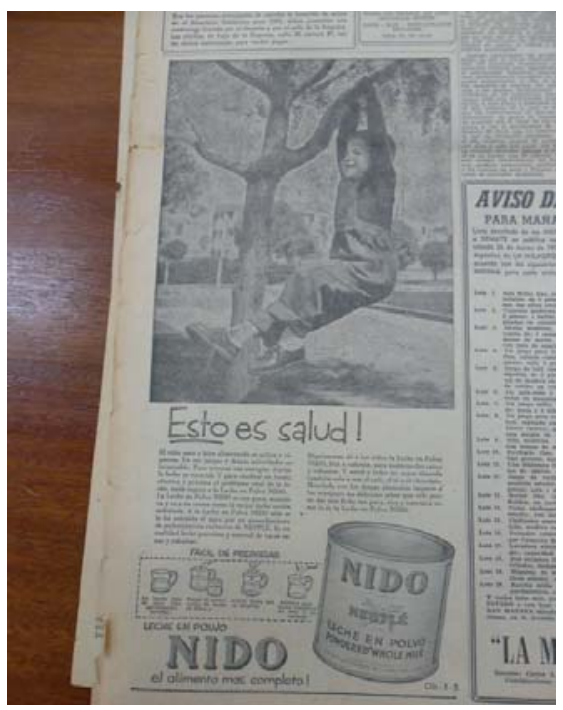

Gráfica 18. Esto es salud. Nido

El Espectador, 25 de marzo de 1955, p.10 
También desde este campo se alude a la tecnificación, pues se resalta como eslogan publicitario que el Seguro Social dispone de modernos elementos científicos para la atención de los pacientes. La modernización de la salud, las comunicaciones, el transporte y la industria es también la modernización de las mentalidades de los usuarios bajo la influencia del modelo estadounidense, como bien puede apreciarse en los siguientes ejemplos:

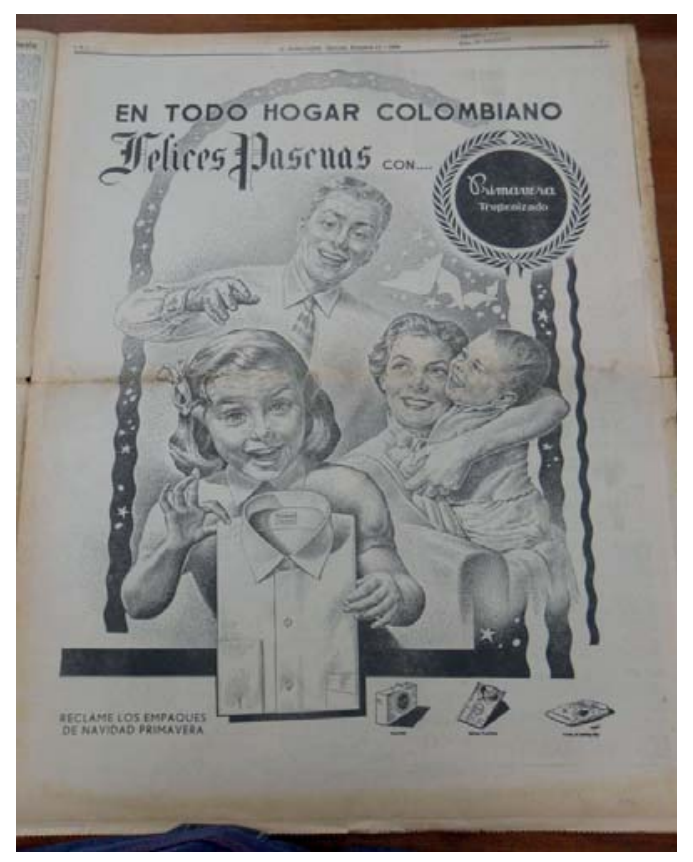

Gráfica 19. En todo hogar colombiano Felices fiestas. Primavera El Espectador. 11 de diciembre de 1955, p. 7

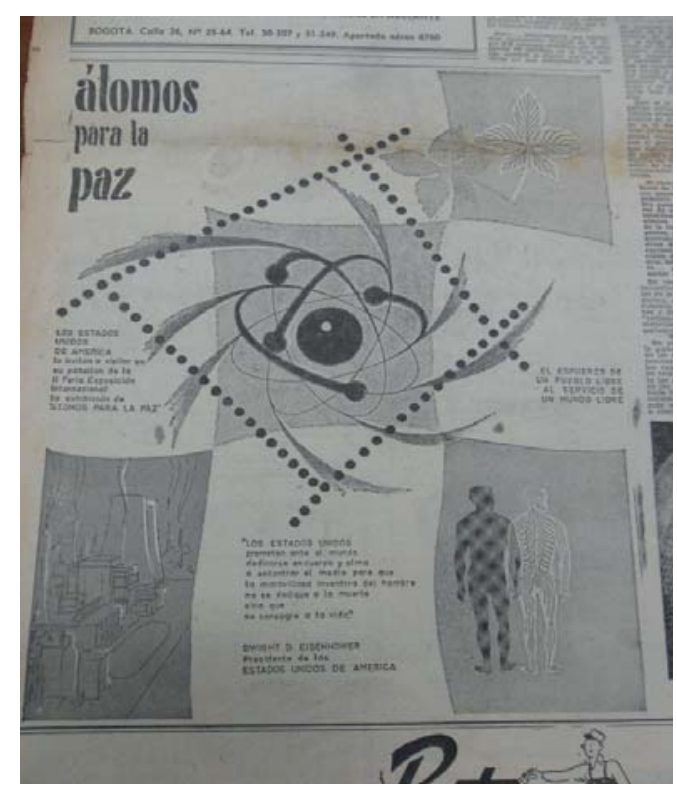

Gráfica 20. Átomos para la paz. Invitación al pabellón de Estados Unidos en la Tercera Exposición Internacional.

El Espectador, 11 de diciembre de 1955, p. 7 


\section{Conclusiones finales}

El gobierno del Teniente General Rojas Pinilla es la prueba fehaciente de cómo el ejercicio de la acción política de control, nacionalista y conservador, apelando a discursos populistas, impuso a la fuerza la idea de Modernidad y progreso. El conjunto de imágenes aquí presentadas son apenas unos ejemplos representativos de las utopías progresistas que se reflejan en las imágenes desacralizadas de revistas y periódicos. Una interpretación de los sistemas de representación de la época vivifica nuevas lecturas de la Modernidad. Lo que refleja el sistema gráfico de la dictadura es el apuntalamiento de una nueva sensibilidad marcada por una temporalidad distinta en la que el espectador se acostumbra a un bagaje de experiencias nuevas que inciden ampliamente en la vida perceptiva y estética de toda la nación. Vale mencionar también que la creación de campañas publicitarias o de propaganda del Estado da cuenta de una socialización vertical en la que prima la trasmisión de conocimientos, normas y comportamientos que se decantan en el sistema social, gracias al poder comunicativo de la imagen. Esta es una poderosa herramienta que determina, difunde e impone valores e ideas, estilos de vida y comportamientos para una sociedad que deja atrás la ruralidad y se inserta en lo urbano bajo las nuevas lógicas del consumo. También puede decirse que la gráfica de la dictadura evidencia en sus discursos un afán por encajar a la fuerza una modernidad totalizadora y avasallante en un país fraccionado cultural y regionalmente. Como testimonio de estos hechos subsisten los fragmentos de la historia cristalizados en imágenes gráficas que permiten el acceso a la interpretación de una parte importante de la vida nacional y que alimentarían relecturas sobre los discursos de exclusión, los procedimientos del poder y los mecanismos de control. Con esto se corrobora que la construcción del significado, del sentido, es netamente un proceso social y que los sistemas de representación son claves para la adaptación e integración del individuo a las sociedades modernas. Por último, el sistema aquí presentado es un ejemplo del peso que la transmisión impositiva y vertical de normas, contenidos y comportamientos tiene a la hora de configurar derroteros ideológicos que guían la realidad.

\section{Referencias bibliográficas}

Bal, M. (2009). Conceptos viajeros en las humanidades: Una guía de viaje. Murcia: Centro de Documentación y Estudios Avanzados de Arte Contemporáneo

Barthes, R. (1999). Mitologías. Madrid: Siglo XXI.

Baudrillard, J. (1978). A la sombra de las mayorías silenciosas. Barcelona: Editorial Kayrós

Bauman, Z. (2016). ¿Para qué sirve realmente un sociólogo? Barcelona: Paidós

Berger, J. (1980). Modos de ver. Barcelona: Gustavo Gili

Boorstin, D. (1961). The image. A guide to pseudoevents in America, New York: Scribner Book.

De Cardona, E. F. (1982). Situación y política de comunicación en Colombia: El caso de la prensa, la radio y la televisión. http://148.206.107.15/biblioteca_digital/articulos/13-306-4809dqg.pdf

Castells, M. (1998). La era de la información. Economía, sociedad y cultura. Vol.2. El poder de la identidad. Madrid: Alianza. 
Català, J. (2005). La imagen compleja. Fenomenología de las imágenes en la era de la cultura visual. Barcelona: Universidad Autónoma de Barcelona

Danto, A. (2003). El cuerpo: el problema del cuerpo. Madrid: Síntesis

Dorfles, Guillo (1969). Nuevos mitos, nuevos ritos. Barcelona: Lumen

Eaglenton, T. (2006). La estética como ideología. Madrid. Trotta

Eco, U. (1997). Apocalípticos e integrados. Barcelona: Lumen

Foucault, M. (1999). Estrategias de poder. Buenos Aires: Paidòs

Foucault, M. (2002). El orden del discurso. Barcelona: Tusquets

Fromm, E. (1979). La crisis de psicoanálisis, Buenos Aires: Paidòs

Galvis, S. E Donadio, A. (1988). El jefe supremo: Rojas Pinilla en la violencia y en el poder. Bogotá: Editorial Planeta.

Gómez, M. (2008). Tres ideas de lo moderno en la concepción del hogar: Bogotá años 50. Bogotà: Universidad Nacional de Colombia

Harawey, D. (1995). Ciencia, cyborgs y mujeres: la reinvención de la naturaleza, Madrid: Ediciones Cátedra

Goodman, N. (1976). Los lenguajes del arte: aproximación a la teoría de los símbolos. Barcelona: Seix Barral

Kracauer, S. (1996). Teoría del cine. La redención de la realidad física. Madrid: Paidós

Lizarazo, D. (2004). Iconos, figuraciones, sueños: hermenéutica de las imágenes. México: Siglo XXI.

Moore, B. (1991).Los orígenes sociales de la dictadura y de la democracia. Barcelona: Ediciones Península,

Pérez, J. (1988). Mito, ideología y utopía: posibilidad y necesidad de una utopía no mitificada. http://www.ugr. es/ pwlac/G06_04JoseAntonio_Perez_Tapias.html

Rodríguez, R. (2006). Pinilla ¿Un dictador? De la dictadura positiva a la dictadura negativa. http://repository. urosario.edu.co/bitstream/handle/10336/2139/80151368.pdf?sequence $=1$

Schütz, A. E Luckmann, T. (1977) La estructura del mundo de la vida. Buenos Aires: Amorrortu Editores.

Vernant, J. P. (2000) Historia de la memoria y memoria histórica. En Barret, F (Dir.), ¿Por qué recordar? (20-28). Barcelona: Edicione Grasset \& Fasquelle.

Wittgenstein, L. (1988). Investigaciones filosóficas. Barcelona: Grijalbo 